\title{
Effect of glutathione (GSH) on Date palm (Phoenix dactylifera L.) micropropagation
}

\author{
Ahmed Madi Waheed Al-Mayahi*, Osama Nazim Jafar, Khaun Ali Mohsen
}

Date Palm Research Centre, University of Basrah, Basrah, Iraq

\begin{abstract}
Al-Mayahi, A.M.W., Jafar, O.N., Mohsen, K.A., 2020. Effect of glutathione (GSH) on Date palm (Phoenix dactylifera L.) micropropagation. Folia Oecologica, 47 (1): 64-69.

The investigation was carried out to evaluate the influence of glutathione (GSH: levels 0, 0.1, 0.5 1.0, and $2.0 \mathrm{mM}$ ) on the callus growth, shoot multiplication and phytochemicals of in vitro shoots of the Date palm cv. Barhee. The optimum concentration of GSH was $1.0 \mathrm{mM}$. Such concentration improved the callus growth and increased its weight to $312.0 \mathrm{mg}$, the addition of this substance of the same concentration level showed the highest response rate and the number of shoots per jar (73.34 \pm 2.69 and $8.83 \pm 0.80$ shoots/jar, respectively). Also, the 1.0 GSH application resulted in reducing the percentage of browning to 0.0 compared to the other concentrations. The results of the biochemical analysis revealed that treatments GSH of $0.1,0.5$ and $1.0 \mathrm{mM}$ reduced the total soluble phenols compound (TSPC). These treatments were also more effectively reducing peroxidase (POD) and phenylalanine ammonia-lyase (PAL) activity than the concentrations of $2 \mathrm{mM}$ or 0 (control treatment).
\end{abstract}

\section{Keywords}

antioxidant substances, browning, phenols compound, phenylalanine ammonia-lyase (PAL), shoot regeneration

\section{Introduction}

Date palm (Phoenix dactylifera $\mathrm{L}$.) of the family Arecaceae is one of the most critical economic fruit crops. The origin of the Date palm is unknown exactly, but it is believed that it originated in southern Iraq at least 6,000 years ago (Al-Yahyai and Manickavasagan, 2012). Date palm is propagated through the use of seeds or offshoots, but both methods suffer from some inadequacies and restrictions (Al-Khateeb, 2006). Therefore, it has become necessary to propagate the Date palm using alternative biotechnology methods. Indeed, Date palm micropropagation enables rapid and large-scale multiplication of uniform plants that are pathogen-free and without pests during plant material exchange, and true-to-type (AL-MAYAHI, 2015). The culture medium is a vital ingredient of the plantlets' growth response that provides most of the requirements for growth and development (JASIM et al., 2009; IBRAHIM et al., 2013; Al-MaYAHI, 2019a). Optimization of the composition of the growth media for micropropagation is fundamental due to the nutrition requirements of the plants. The $\gamma$-glutamylcysteinyl glycine it's called glutathione and too GSH-reduced $\left(\mathrm{C}_{10} \mathrm{H}_{17} \mathrm{~N}_{3} \mathrm{O}_{6} \mathrm{~S}\right)$ is a water-soluble tripeptide that possesses active thiol compound that contributes to cell division and organ differentiation in most plant species (VIEIRA et al., 2012; FraGa et al., 2016). Usually supplied culture media with the GSH is used to enhancing cell regeneration and the development of immature somatic embryos (STASOlla et al., 2004). The different roles and functions of antioxidants, including glutathione, open vast possibilities to use them to promote tissue culture and plant regeneration. As well as the decisive role of GSH in regulating organogenesis, regeneration, and differentiation of cultures propagated in vitro (BELMONTE 
et al., 2006; TyBURSKI and TRETYN, 2010) plays a role. Therefore, in this investigation, we concentrate on the attempt to evaluate the effects of glutathione, as one of the most effective antioxidants, which is supplemented in the MS culture media, and its role in developing a possible improved protocol for propagation of Date palm cv. Barhee in vitro.

\section{Materials and methods}

\section{Plant and culture establishment}

Callus tissues induced from the apical buds of the Date palm cv. Barhee were separated and cultured on a medium composed of (MS) (Murashige and SKoog, 1962) $\left(4.4 \mathrm{~g} \mathrm{ml}^{-1}\right)$, with additional $10 \mathrm{mg}^{-1}$ Naphthalene Acetic Acid (NAA), $2 \mathrm{mg} \mathrm{l}^{-1} 2 \mathrm{iP}$ and $3 \mathrm{~g} \mathrm{l}^{-1}, 100 \mathrm{mg} \mathrm{l}^{-1}$ glutamine, $5 \mathrm{mg} \mathrm{l}^{-1}$ thiamine $\mathrm{HCl}, 1 \mathrm{mg} \mathrm{l}^{-1}$ biotin, $30 \mathrm{~g} \mathrm{l}^{-1}$ sucrose, and solidified with agar at $7.0 \mathrm{~g} \mathrm{l}^{-1}$ and $1.5 \mathrm{~g} \mathrm{l}^{-1}$ activated charcoal. After getting the sufficient amount of callus, we transferred it to MS medium with the same composition mentioned previously, excluding growth regulators combination $\left(0.5 \mathrm{mg}^{-1} \mathrm{NAA}, 0.5 \mathrm{mg} \mathrm{l}^{-1} \mathrm{BA}\right.$, $0.5 \mathrm{mg} \mathrm{l}^{-1}$ kinetin $\left.(\mathrm{K})\right)$, and $0.5 \mathrm{~g} \mathrm{l}^{-1}$ activated charcoal (AL-MAYAHI, 2016), suitable for shoot regeneration.

To study the effects of glutathione on the multiplication of buds and changes in phytochemicals, MS culture media were equipped with different concentrations of GSH $(0$, $0.1,0.5,1.0$, and 2.0$) \mathrm{mM} \mathrm{1}^{-1}$. The $\mathrm{pH}$ of the medium was adjusted between 5.7-5.8 with $0.1 \mathrm{~N} \mathrm{NaOH}$ or $\mathrm{HCl}$ before the addition of agar. Sterilization of the culture's jars with media was performed by autoclaving at $121{ }^{\circ} \mathrm{C}$ and pressure of $1.04 \mathrm{~kg} \mathrm{~cm}^{-2}$ for $20 \mathrm{~min}$. The cultures were incubated under room temperature $25 \pm 2{ }^{\circ} \mathrm{C}$, with a $16 \mathrm{~h}$ photoperiod provided by white fluorescent lamps. The results of the experiments evaluated after 12 weeks of culture callus on the media were: percentage of shoot regeneration and shoot numbers.

\section{Browning percentage (\%)}

The browning percentages were scored according to the following: - No shoot browning, + Moderate shootbrowning, +++ Severe shoot-browning.

\section{Total soluble phenols compound (TSPC)}

TSPCs were estimated with the Folin-Ciocalteu reagent according to the method described by SADASIVAM and MANICKAM (1996). The absorbance temperature $(650 \mathrm{~nm})$ was measured by using a spectrophotometer; results were expressed as (mg GAE/g).

\section{POD and PAL assay}

Peroxidase (POD) was measured as described by DiAz et al. (2001). Phenylalanine ammonia-lyase (PAL) activity was assayed following the method of (SYKLOWSKABARANEK et al., 2012).

\section{Statistical analysis of data}

Data from each experiment were subjected to One-way Analysis of Variance (ANOVA). A completely random CRD was used. The GenStat software was applied. All significant means were separated using the least significant difference $(\mathrm{P}<0.05)$.

\section{Results}

Effect of various concentrations of glutathione on some growth criteria

\section{Callus growth}

According to the results obtained in Fig. 1, glutathione at $(0.1,0.5$, and 1.0) $\mathrm{mM}$ was found suitable for producing callus. However, the weight of callus was decreased with an increase in the concentration of glutathione to $2 \mathrm{mM}$ in the culture media (Fig. 2e). The weight of callus was increased in the media containing glutathione at $1.0 \mathrm{Mm}$, which was $312.0 \mathrm{mg}$. This value was higher than that in the media supplemented with the other of glutathione concentrations. The statistical analysis shows significant differences between $2.0 \mathrm{Mm}$ of GSH and control (no additives) treatment on callus weight at the 0.05 level (Fig. 1 and Fig. 2a, e).

\section{The percentage of indirect multiplication and shoots} production

The cultured buds showed significant variations in their response percentage, as well as the formation of shoots, under the influence of different concentrations of GSH (Fig. 3). Tissues cultured in medium containing GSH at $1.0 \mathrm{~mm}$ showed a better response rate $(73.34 \pm 2.69 \%)$ of buds producing shoots and average shoots number $(8.83$ \pm 0.80 shoots/jar) compared to tissues cultured in the medium containing $2 \mathrm{mM} \mathrm{GSH}$ which recorded the lowest response rate with the lowest number of shoots which were $33.34 \%$ and $3.97 \pm 0.81$ shoots, respectively (Table 1, Fig. 3e).

\section{Browning percentage}

The results in Fig. 2e showed that the treatment of GSH at $2.0 \mathrm{mM}$ resulted in severe browning in most cultures +++ . Control treatment ( $0.0 \mathrm{GSH})$ showed a moderate browning rate $(+)$ (Fig. 2a), while the browning response was not recorded in the GSH treatments at $0.1,0.5$ and 1.0 Mm (Fig. 2b, c, and d).

\section{Impact of glutathione on some biochemical traits}

\section{Total soluble phenols compound (TSPC)}

The data in Fig. 4 show that the optimal treatment was observed in the medium containing $0.1,0.5$, and $1.0 \mathrm{mM}$ of glutathione, which showed significant superiority in reducing the content of the cultures of total soluble phenols compound compared with other treatments. It also showed the results of biochemical analyses that phenolic compounds were increased with increasing levels of glutathione to $2 \mathrm{mM}$, where it reached $1.53 \mathrm{mg}$ 


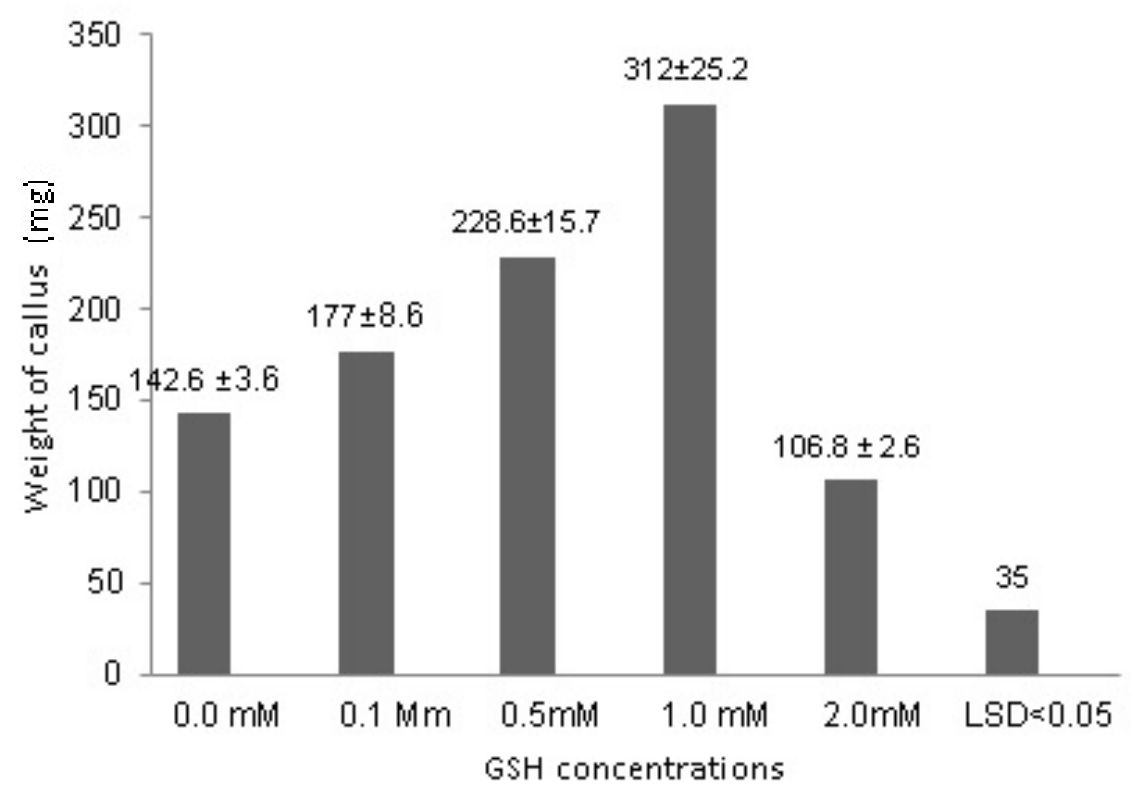

Fig. 1. Effect of different glutathione (GSH) concentrations on the weight of callus (mg) in the Date palm cv. Barhee in vitro ( \pm Standard error).

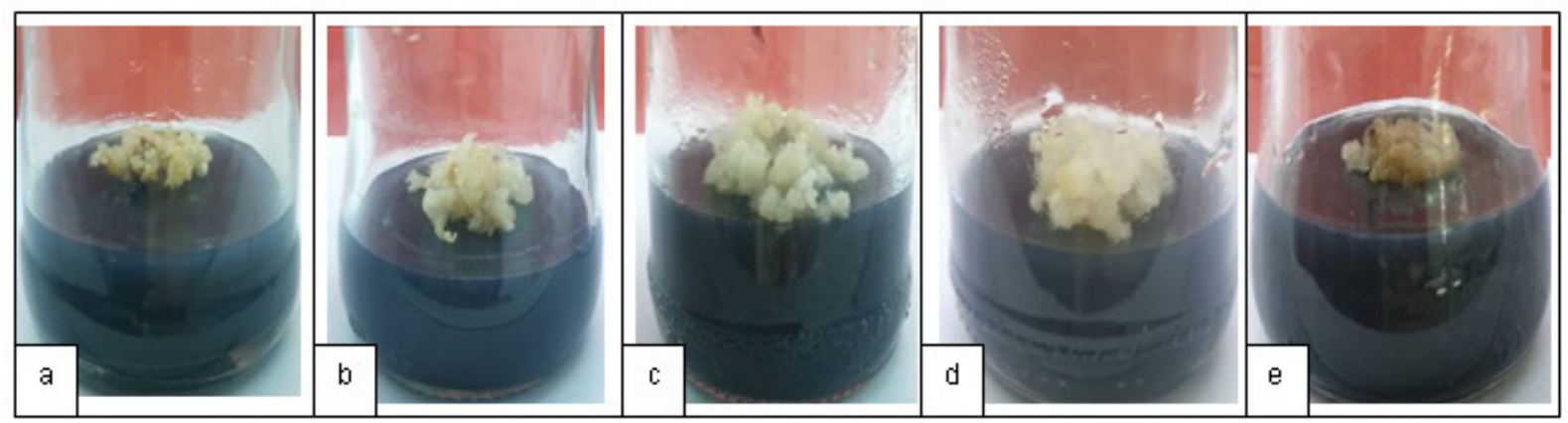

Fig. 2. Callus proliferation on MS medium with (a) control (0.0 mM GSH), (b) $0.1 \mathrm{mM} \mathrm{GSH}$, (c) $0.5 \mathrm{mM} \mathrm{GSH}$, (d) $1.0 \mathrm{mM}$ $\mathrm{GSH}$, (e) $2.0 \mathrm{mM}$ GSH treatments.

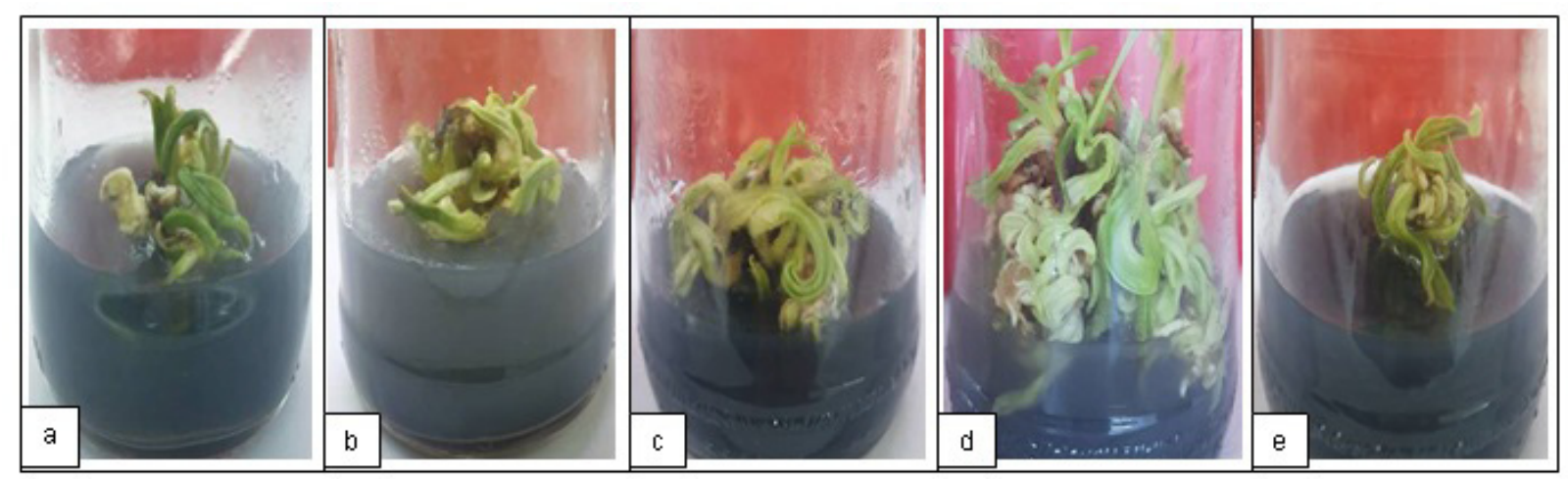

Fig. 3. Effect of different concentrations of glutathione (GSH) on the bud induction in the Date palm callus cv. Barhee:(a) control (0.0 mM GSH), (b) $0.1 \mathrm{mM} \mathrm{GSH}$, (c) $0.5 \mathrm{mM} \mathrm{GSH}$, (d) $1.0 \mathrm{mM} \mathrm{GSH}$, (e) $2.0 \mathrm{mM} \mathrm{GSH}$.

GAE/g. Results also showed the accumulation of phenolic compounds reached $1.35 \mathrm{mg} \mathrm{GAE} / \mathrm{g}$ at the control treatment. 


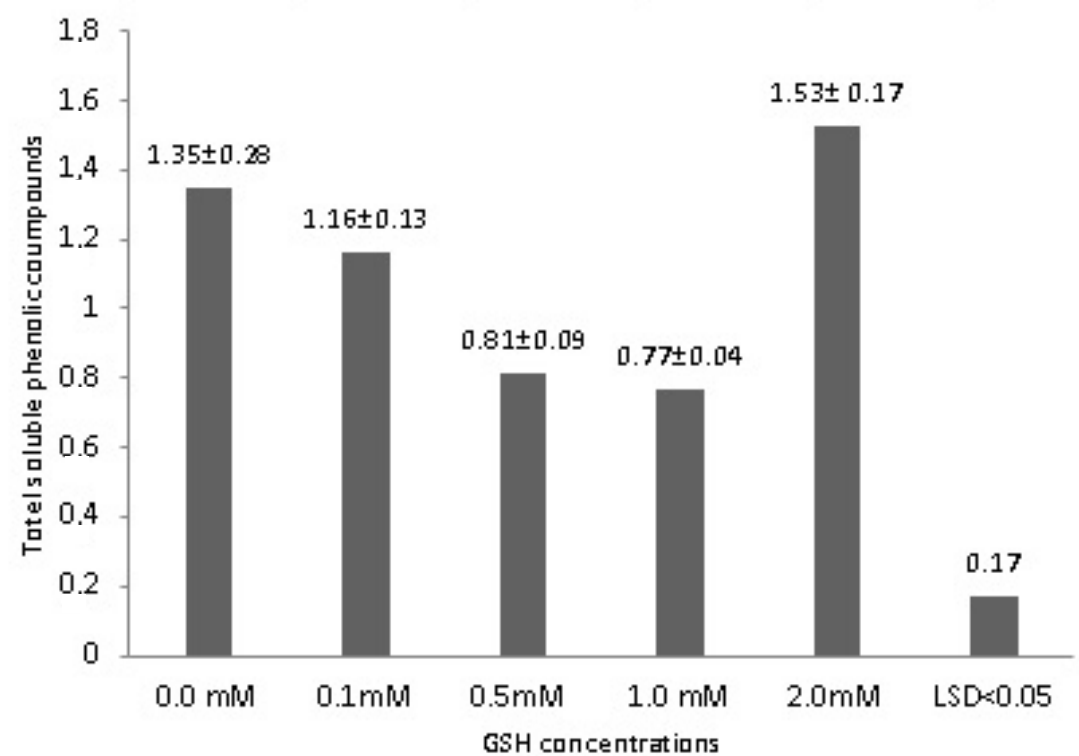

Fig. 4. Effect of GSH concentration on total soluble phenols compounds of Date palm tissues cv. Barhee ( \pm Standard error).
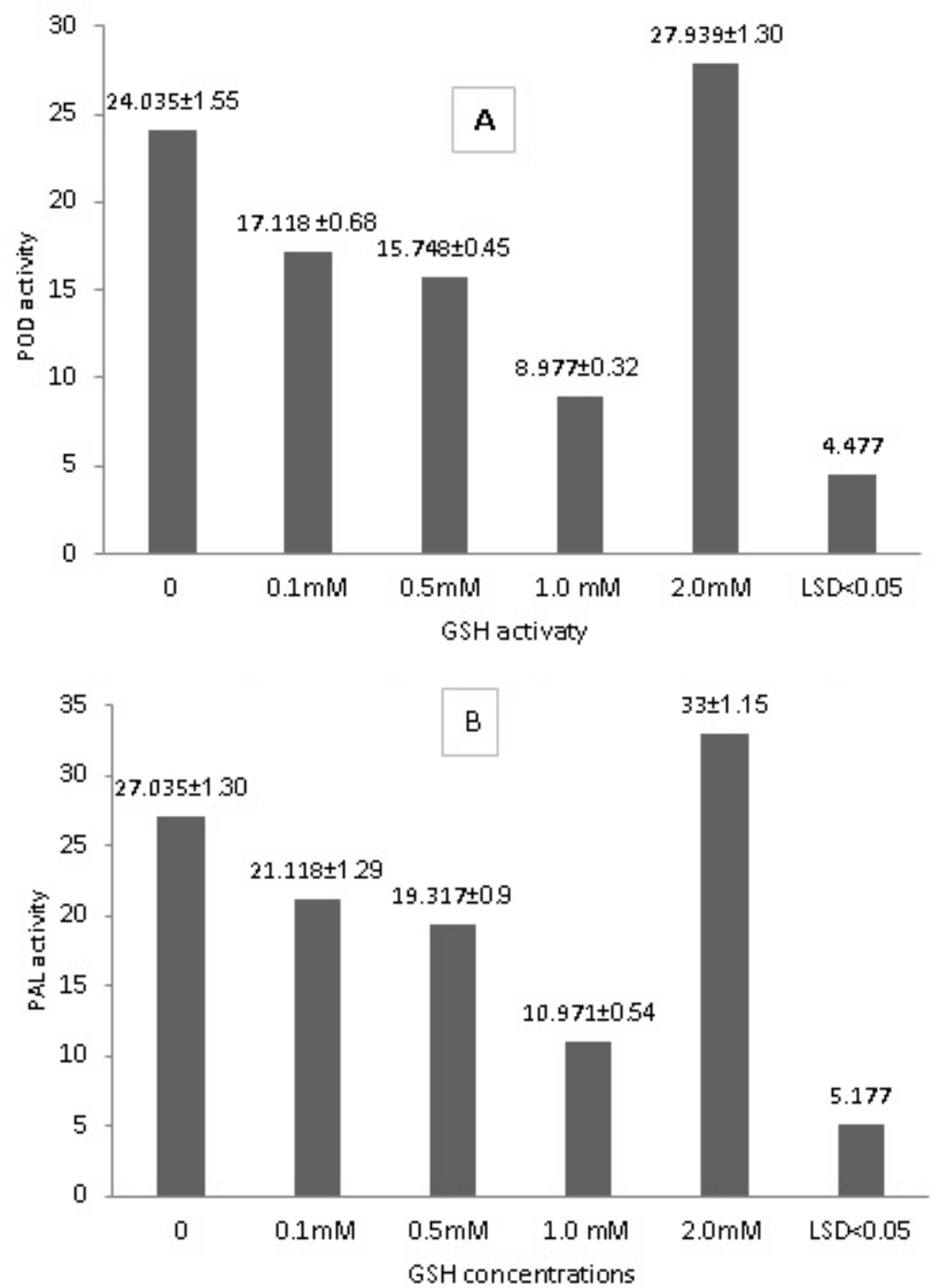

Fig. 5. Effect of glutathione (GSH) concentrations on activity of (a) peroxidase (POD), (b) phenylalanine ammonia-lyase $(\mathrm{PAL})$ in in vitro cultured Date palm cv. Barhee ( \pm Standard error). 
Table 1. Effect of glutathione (GSH) on the response percentage of callus for shoot regeneration and number of shoots $( \pm$ Standard error)

\begin{tabular}{ccc}
\hline Treatments $(\mathrm{mM})$ & $\begin{array}{c}\text { Response } \\
\text { percentage }(\%)\end{array}$ & $\begin{array}{c}\text { No. of } \\
\text { shoots } / \text { jar }\end{array}$ \\
\hline 0.0 control & $40.00 \pm 1.53 * \mathrm{c}$ & $4.53 \pm 0.84 \mathrm{c}$ \\
0.1 & $53.34 \pm 1.81 \mathrm{~b}$ & $6.50 \pm 0.47 \mathrm{~b}$ \\
0.5 & $60.00 \pm 1.85 \mathrm{~b}$ & $6.93 \pm 0.58 \mathrm{~b}$ \\
1.0 & $73.34 \pm 2.69 \mathrm{a}$ & $8.83 \pm 0.80 \mathrm{a}$ \\
2.0 & $33.34 \pm 1.20 \mathrm{c}$ & $3.97 \pm 0.81 \mathrm{c}$ \\
LSD P $<0.05$ & 13.33 & 1.07 \\
\hline
\end{tabular}

*Different letters indicate statistically significant differences between means.

Peroxidase (POD) and phenylalanine ammonia-lyase (PAL) activity

The statistical analysis showed that the treatment of GSH at $2.0 \mathrm{mM}$ GSH recorded the highest activity of both POD and PAL (27.94 and 33.0\%) respectively, which was significantly different compared to the activity of the above-mentioned antioxidant enzymes at other treatments $(\mathrm{p}<0.05)$ (Fig. 5a, and b). While the lowest activity of antioxidant enzymes, POD and PAL were achieved at treatment $1.0 \mathrm{mM}$ GSH, which were 8.977 , and 10.71 respectively.

\section{Discussion}

The results of this study showed that the gradual increase in the concentration of $\mathrm{GSH}$ to $1.0 \mathrm{mM}$ in the culture medium enhanced good response, but at higher levels $(1.0 \mathrm{mM})$ significantly depressed the shoot proliferation. Cultures on growth medium containing $1.0 \mathrm{mM}$ GSH stimulated callus proliferation, which reflected positively on the increase its weight. The different biochemical properties of GSH enable the potential to participate in plant growth and development where the addition of glutathione $(\mathrm{GSH})$ to the growth media improved shoot organogenesis. These data suggest that the process of shoots regeneration is dependent on optimal GSH levels in the culture media and that the mechanism of inhibition of shoots growth by GSH may occur as a result of the accumulation of supraoptimal GSH levels in the cultured tissues. Tissue analysis demonstrated that the presence of GHS is necessary for the persistence of cell divisions (Vernoux et al., 2000). GSH was found in cells that are characterized by their active division. At the same time, it was not present in cells that are characterized by their slow division, which indicates that developing tissues require glutathione (TyBurski and Tretyn, 2010). Providing the media with GSH contributed to stimulating growth when applied with levels that suit the physiological levels. Our results are in harmony with those obtained by BELMONTE et al. (2006), TYBURSKI and TRETYN (2010), who reported the critical role of GSH in organogenesis and differentiation in vitro. One of the most significant constraints facing the in vitro tissue of the Date palm is the browning that causes tissue damage a few days after cultivation (AL-MAYAHI et al., 2010; AL-MAYAHI, 2014). Browning is a significant obstacle to the successful exploitation of these vital trees (AL-MAYAhI, 2018 and 2019b). Browning of tissues occurs as a result of increased production of TSPCs and their consequent oxidation by the activity of polyphenol oxidase (PPO). GUAN et al. (2019) mentioned that PAL is the main enzyme that participates in the first step for the biosynthesis of phenylpropanoid. Through these results, a positive relationship can be observed in the activity of PAL and TSPCs, indicating an increase in the content of TSPCs due to increased PAL activity. As ANDERSONE and IEVIENSH (2002) reported that the POD and PAL oxidizing enzymes are the stimulants of biosynthesis of polyphenols, as well as they contribute to browning due to wounds, these enzymes are an indicator of oxidative metabolism. In this study, we observed a decrease in PAL and POD activity in GSH-treated cultures accompanied by reduced TSPCs. Many previous studies indicated that GSH has the potential for practical use to control TSPCs (TABIYEH et al., 2006). Glutathione plays major regulatory roles in the process of the cell cycle progress within the meristems, as it is participating in the redox-dependent determination of regeneration and quiescence patterns (TYBURSKI and Tretyn, 2010). TABIYEH et al. (2006) reported that the treatment with GHS led to decrease phenylalanine ammonia-lyase PAL activity, which may be caused by a reduction in secondary metabolism production and the browning of tissues in favour of primary metabolism processes supporting the increase of growth. Browning tissue discoloration was associated with oxidative stress which was also supported by a higher content of TSPCs (MisRa et al., 2010). Therefore, GSH can be usefully used to decrease the browning of tissue. The low activity of antioxidant enzymes resulting from treatment with antioxidants confirms the conclusions of TABIYEH et al. (2006), who concluded that GSH reduced the enzymes' antioxidant activity.

\section{Conclusions}

From the results of this study we concluded that treatment with different concentrations of glutathione $(0.1,0,5$ and 1.0) $\mathrm{mM}$ had a significant effect on most of the studied traits, the results showed that inhibit peroxidase (POD) and phenylalanine ammonia-lase activity (PAL), it was associated with inhibiting the production of TSPCs, it also coincided with the promotion of callus growth and buds development and reduced the browning of tissues cultured as compared to the concentration of $2.0 \mathrm{GSH}$ and 0.0 (control treatment). $1.0 \mathrm{mM}$ GSH showed its superiority in all studied traits.

\section{References}

Al-KhateEb, A., 2006. Role of cytokinin and auxin on the multiplication stage of date palm (Phoenix dactylifera L.) cv. Sukry. Biotechnology, 5 (3): 349-352. 
Al-Mayahi, A.M.W., Ahmed, A.N., Al-Khalifa, A.A., 2010. Isolation and identification of associated fungi with the micropropagation of five different date palm cultivars and the effect of Benlate fungicides in their control. Basrah Journal for Date Palm Research, 9 (2): 79-97.

Al-Mayahi, A.M.W., 2014. Effect of copper sulphate and cobalt chloride on growth of the in vitro culture tissues for date palm (Phoenix dactylifera L.) cv. Ashgar. American Journal of Agricultural and Biological Sciences, 9 (1): 6-18.

Al-Mayahi, A.M.W., 2015. An efficient protocol for indirect somatic embryogenesis and shoot organogenesis from leaf segments of date palm (Phoenix dactylifera L.) cv. Quntar. African Journal of Agricultural Research, 10 (10): 10311042.

AL-MaYAhI, A.M.W., 2016. Influence of salicylic acid (SA) and ascorbic acid (ASA) on in vitro propagation and salt tolerance of date palm (Phoenix dactylifera L.) cv. 'Nersy'. Australian Journal of Crop Science, 10 (7): 969-976.

Al-Mayahi, A.M.W., Ali, A.H., ShareEF, H.J., 2018. Influence of cold pretreatment on shoot regeneration from callus in date palm (Phoenix dactylifera L.) cv. 'Barhee'. Journal of Genetic Engineering and Biotechnology, 16: 607-612.

Al-MaYAhi, A.M.W., 2019a. Effect of aluminum on the growth of the in vitro culture tissues of the date palm (Phoenix dactyliferaL.) cv. Um-Adelhin. Folia Oecologica, 46 (2): 164-169.

Al-Mayahi, A.M.W., 2019b. Effect of calcium and boron on growth and development of callus and shoot regeneration of date palm cv. Barhee. Canadian Journal of Plant Science. E-first article. [cit. 2020-01-030]. https://doi. org/10.1139/CJPS-2019-0084

Al-Yahyai, R., Manickavasagan, A., 2012. An overview of date palm. In Manickavasagan, A., Mohamed, E.M., SuKumar, E. (eds). Dates: production, processing, food and medicinal values. Florida: CRC Press, p. 3-11.

Andersone, U., IEviensh, G., 2002. Changes of morphogenic competence in mature Pinus sylvestris L. buds in vitro. Annals of Botany, 90: 293-298.

Belmonte, M.F., Ambrose, S.J., Ross, A.R.S., Abramse, S.R., Stasolla, C., 2006. Improved development of microspore-derived embryo cultures of Brassica napus $\mathrm{cv}$ Topaz following changes in glutathione metabolism. Physiologia Plantarum, 127: 690-700.

Diaz, J., Bernal, A., Pomare, F., Marino, F., 2001. Induction of shikimate dehydrogenase and peroxidase in pepper (Capsicum annum L.) seedlings in response to copper stress and its relation to lignification. Plant Science, 161: $179-188$

Fraga, H.P.F., Vieira, L.N., Puttkammer, C.C., Santos, H.P., Garighan, J., Guerra, M.P., 2016. Glutathione and abscisic acid supplementation influence somatic embryo maturation and hormone endogenous levels during somatic embryogenesis in Podocarpus lambertii Klotzsch ex Endl. Plant Science, 253: 98-106.

Guan, Y., Hu, W., Jiang, A., Xu, Y., SA, R., Feng, K., ZhaO, M., Yu, J., Ji, Y., Hou, M., Yang, X., 2019. Effect of methyl jasmonate on phenolic accumulation in wounded broccoli. Molecules, 24 (19): 3537.

Ibrahim, M.A, WaheEd, A., AL-TAha, H.A., 2013. Plantlet regeneration from root segments of date palm tree (Phoenix dactylifera L. cv. Barhee) producing by in vitro culture. Advances in Agriculture \& Botanics, 5 (1): 4550 .

Jasim, A.M., Al-Mayahi, A.M.W., Aтtaha, A.H.M., 2009. Propagation of four rare cultivars of date palm (Phoenix dactylifera L.) by tissue culture techniques. Basrah Journal for Date Palm Research, 8 (1): 72-99.

Misra, P., Toppo, D.D., Gupta, N., ChaKrabarty, D..Tuli, R., 2010. Effect of antioxidants and associated changes in antioxidant enzymes in controlling browning and necrosis of proliferating shoots of elite Jatropha curcas L. Biomass and Bioenergy, 34 (12): 1861-1869.

Murashige, T., Skoog, F., 1962. A revised medium for rapid growth and bioassays with tobacco tissue cultures. Physiologia Plantarum, 15: 473-497.

Sadasivam, S., Manickam, A., 1996. Biochemical methods. New Delphi: New Age International. $256 \mathrm{p}$.

Stasolla, C., Belmonte, M. F., Van Zyl, L., Craig, D. L., Liu, W., Yeung, E. C., Sederoff, R. R., 2004. The effect of reduced glutathione on morphology and gene expression of white spruce (Picea glauca) somatic embryos. Journal of Experimental Botany, 55 (397): 695-709.

SyklowsKa-BaraneK, K., Pietrosiuk, A., NALIWAJSki, M.R., KaWiak, A., Jeziorek, M., WydersKa, S., ŁoJKowsKa, E., Chinou, I., 2012. Effect of 1-phenylalanine on PAL activity and production of naphthoquinone pigments in suspension cultures of Arnebia euchroma (Royle) Johnst. In Vitro Cellular \& Developmental Biology, 48: 555-564.

TABIYEH, D.T., BERNARD, F.,SHACKER, H., 2006. Investigation of glutathione, salicylic acid and $\mathrm{GA}_{3}$ effects on browning in Pistacia vera shoot tips culture. Acta Horticulturae, 726: 201-204.

TYBURSKI, J, TRETYN, A ., 2010. Ascorbate and glutathione in organogenesis, regeneration, and differentiation in plant in vitro cultures. In ANJUM, N.A., UMAR, S., CHAN, M. (eds). Ascorbate-glutathione pathways and stress tolerance in plants. Dordrecht: Springer, p. 55-90.

Vernoux, T., Wilson, R.C., Seeley, K.A., Reichheld, J.P., Muroy, S., Brown, S., Maughan, S.C., Cobbett, C.S., Van Montagu, M., Inze, D., May, M.J., Sung, Z.R., 2000. The root meristemless1/cadmium sensitive2 gene defines a glutathione-dependent pathway involved in initiation and maintenance of cell division during postembryonic root development. Plant Cell, 12:97-109.

Vieira, L.N., Santa-Cataina, C., Fraga, H.P.F., Santos, A.L.W., Steinmacher, D.A., Schlogei, P.S.,Guerra, M.P., 2012. Glutathione improves early somatic embryogenesis in Araucaria angustifolia (Bert) $\mathrm{O}$. Kuntze by alteration in nitricoxide emission. Plant Science, 195: 80-87.

Received February 6, 2020 Accepted April 5, 2020 